\title{
Free and Depedent Small Clauses in Brazilian Portuguese*
}

(Mini-Orações Livres e Dependentes em Português Brasileiro)

\author{
Mary Aizawa Kato \\ (Universidade Estadual de Campinas)
}

\begin{abstract}
This paper examines free small clauses, which, unlike dependent small clauses, exbibit peculiar properties: (a) they are restricted to occur with individual level and event adjectives, (b) they have to appear with the subject postposed. After considering several hypotheses on the nature of this inversion, it is proposed that these adjectives are of the ergative type, while the stage level adjectives are unergatives. Small clauses with ergative adjectives can be complements of a third copula distinct from the attributive 'ser' and the stative 'estar', which underlies cleft constructions. The derivation of free small clauses is parallel to canonical cleft sentences.
\end{abstract}

KEY-WORDS: small clauses; word order; adjectives; copula.

RESUMO: Este artigo examina o que chamamos de mini-oraçöes livres, que, diferentemente de mini-orações dependentes, exibem algumas propriedades peculiares: (a) é restrita a ocorrer com adjetivos de indivíduo ou de evento, (b) tem que ter o sujeito posposto. Após considerar várias hipóteses sobre a natureza dessa inversão, propôs-se que os adjetivos que nela aparecem são do tipo ergativo. Essas mini-orações podem ser complementos de um tipo especial de cópula, do tipo que aparece com construçoes clivadas. As derivações das mini-oraçỗes livres seriam paralelas à derivação de construções clivadas. PALAVRAS-CHAVE: mini-orag̃ös; ordem das palavras; adjetivos; cópula.

\section{The data and the problem}

The aim of this paper is to discuss the order of constituents in Brazilian Portuguese, hereafter BP, inside constructions that have been called 'small clauses' and to try to relate this order to what occurs in finite sen-

\footnotetext{
* This work was supported by CNPq (grant 303274/2005-0) and FAPESP (Projeto Temático 2006/00965-2). I would like to thank Cilene Rodrigues for her comments and suggestions, as editor, and Andrew Nevins for his kind language revision.
}

D.E.L.T.A., 23:esp., 2007 (85-111) 
tences. The primary aim is to analyze the nature of the peculiar case of BP free small clauses like those in $(1):^{1}$

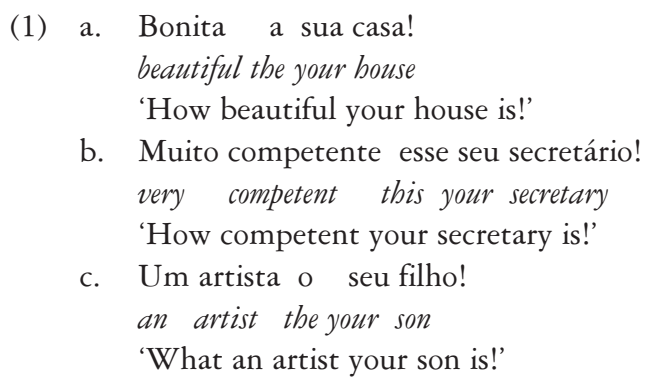

Two kinds of small clauses have been proposed in the literature: those that function as complements (examples (2)) and those that function as adjuncts (examples (3)): ${ }^{2}$

(2) a. Considero os meninos inocentes consider-1Sg the-Pl boys innocent-Pl 'I consider the boys innocent'

b. Maria achou o João um gênio Maria found the-Sg João a genius 'Maria found João to be a genius'

c. Eu vi as visitas saindo I saw the-Pl guests leaving

'I saw the guests leaving'

(3) a. Eu como as cenouras cruas I eat-1Sg the-Pl carrots raw-Pl 'I ate the carrots raw'

b. Encontrei o dinheiro escondido found-1Sg the-Sg money-Sg bidden-Sg 'I found the money hidden'

Verbs that require small clause complements can be of two types: exceptional case marking verbs (ECM), like the ones in (2)-(3), and raising verbs like 'parecer' (seem) below:

\footnotetext{
1 We will leave out small clauses with NPs (like the one in (1c)) and PPs, and concentrate our study on AP small clauses.

2 We will translate only the number inflection in the glosses, but gender is also inflected in these cases.
} 
(4) a. [[os meninos $]_{i}$ parecem $\left[t_{\mathrm{i}}\right.$ inocentes $\left.]\right]$

the-Pl boys seem-3Pl innocent-Pl

'The boys seem innocent'

b. $[\text { [essa conversa }]_{\mathrm{i}}$ soa $\left[t_{\mathrm{i}}\right.$ falsa $\left.]\right]$

this-Sg talk-Sg sounds false-Sg

'This talk sounds false'

c. [[os soldados $]$ continuam $\left[t_{\mathrm{i}}\right.$ feridos $\left.]\right]$

the-Pl soldiers continue- $3 P l$ wounded-Pl

'The soldiers are still wounded'

Along the forms presented in (1)-(4) Portuguese has the following forms, in which the small clause subject and its predicate appear in inverted positions:

(5) a. Considero inocentes os meninos consider-1Sg innocent-Pl the-Pl boys

'I consider the boys innocent'

b. Maria acha um gênio o João

Maria finds a-Sg genius-Sg the João

'Maria finds João to be a genius'

c. Eu vi sairem as visitas

I saw-1Sg leave-3Pl the-Pl guests

'I saw the guests leaving'

d. Eu como cruas as cenouras

$I$ eat-1g raw-Pl the- $P$ l carrots

'I eat the carrots raw'

e. Encontrei escondido o dinheiro

found-1Sg bidden-Sg the-Sg money-Sg

'I found the money hidden'

Not only ECM verbs, but also raising verbs, can have inversion inside their small clause complements:

(6) a. Parecem inocentes os meninos

seem-3Pl innocent- $P l$ the- $P l$ boys

'The boys seem innocent'

b. Soa falsa essa conversa

sounds false-3Sg this talk- $\mathrm{Sg}$

'This talk sounds fake'

c. Continuam feridos os soldados

continue- $3 P l$ wounded-Pl the-Pl soldiers

'The soldiers are still wounded' 
As for free small clauses, the puzzling fact about them is that they can only appear in the inverted form: ${ }^{3}$

(7) a. *A sua casa bonita the your house beautiful

b. *Esse seu secretário muito competente this your secretary very competent

c. *O seu filho um artista the your son an artist

Moreover, the adjectives that appear in these free small clauses are of the type that appears in the complement of consider type verbs.

(8) a. Acho inteligentes esses meninos

find-1Sg intelligent-Pl these boys

'I find these boys intelligent'

b. *Acho bêbados esses homens

find-1Sg drunk-Pl these men

c. Inteligentes esses meninos

intelligent-Pl these boys

'How smart these boys are'

d. * Bêbados esses homens

drunk-Pl these men

Given these data, this paper will address the following questions:

(i) What is the internal structure of free and dependent small clauses?

(ii) What sort of inversion do we have in them?

(iii) Why is it that free small clauses cannot appear in the subject-predicate order as their dependent counterpart forms can?

(iv) Do BP free small clauses share any property with children's small clauses?

In section 2, I will present the two main proposals concerning the internal structure of dependent small clauses - the clausal hypothesis and the non-clausal hypothesis, arguing in favor of the clausal one. In section

3 The examples in (7) are acceptable when interpreted as noun phrases. My point here is that they cannot achieve the free relative clause interpretation observed in (1). 
3, I will study the order of the predicate phrase in relation to its subject $\mathrm{NP}$, discussing four analyses considered in the inversion phenomenon in finite sentences: restructuring (section 3.1), the V-to-Comp analysis (section 3.2), ergative inversion (section 3.3), and Romance inversion (section 3.4). In section 4, I will present my analysis. In section 5, I will compare BP free small clauses with small clauses in children.

\section{The internal structure of small clauses}

All the analyses in the generative framework consider the highlighted sequences in (1)-(7) as containing a predication relation and the relevant $\mathrm{NP}$ as the subject in this relation. Two proposals have been presented in the literature to account for this relation: First (cf. (9)), the NP is in a clausal, or small clause relation with its predicate (cf. Stowell 1981, Chomsky 1981, Kitagawa 1985, Kuroda 1986, Chung \& McCloskey 1987, and Stowell 1991). Second (cf. (10)), the predication relation is a function of this NP and the XP being co-indexed, with no requirement that the two be dominated by a clausal node (cf. Williams 1983, Emonds 1985).

(9)

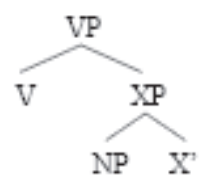

(10)

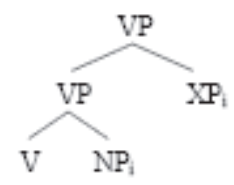

Two different versions of the clausal hypothesis can be further found: (9) according to which the subject is the specifier of the X' phrase (Stowell, 1981) and (11) that defines the predication relation strictly in terms of the two maximal projections c-commanding each other (cf. Rothstein 1983):

(11)

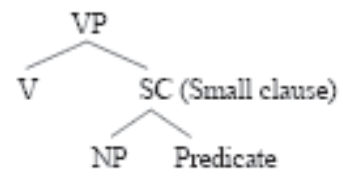

Rothstein (1983), the proponent of representation (11) for small clauses, restricts its scope to main verbs that select a proposition, but not to cases like examples (4) and (5), in which the main verb selects entities and 
not propositions. For examples such as (4) and (5), Rothstein proposes a structure of adjunction like the one in (12), which she takes to be cases of secondary predication relations:

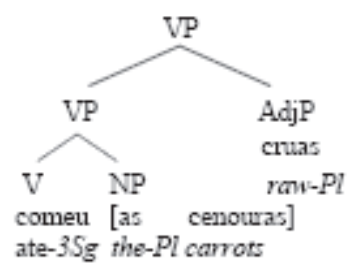

In small clauses with a primary predication relation, the main verb selects a predicate, which in turn selects a thematic argument. The modified NPs in examples (1), (2) and (3) are not, therefore, arguments of the main verb, but of the small clause predicate. In the secondary predication (12), according to Rothstein, the predication relation holds directly of the NP cenouras and the adjunct cruas. Safir (1984) claims, however, that the predicate cruas requires an independent theta-role and, therefore, the structure should be represented as in (13), with an empty category in the small clause (PRO) controlled by the object of the main verb:

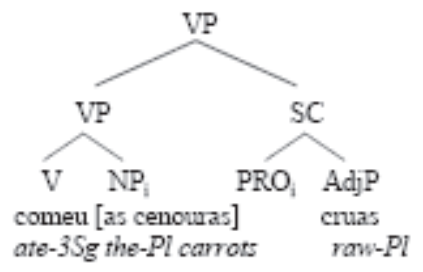

The arguments presented in the literature in favor of the clausal analysis are in greater number than the arguments against it, and the existence in Brazilian Portuguese of independent, or free small clauses, namely small clauses that are not complements or adjuncts in a sentence, adds strong empirical support to this hypothesis. As the constituents of the independent small clauses do not appear as sisters to a main clause verb, they will necessarily be dominated by a node in a clause-mate relationship.

In view of this conclusion regarding the structure of small clauses, we will examine the questions related to the inversion problem having the clausal hypothesis in mind. 


\section{The nature of inversion}

\subsection{The re-structuring, or incorporation bypothesis}

The first hypothesis that I would like to consider is that inverted structures result from incorporation of the small clause predicate into the matrix verb, forming what has been called a complex predicate The representation of the adjective incorporated to the verb would be as shown below:

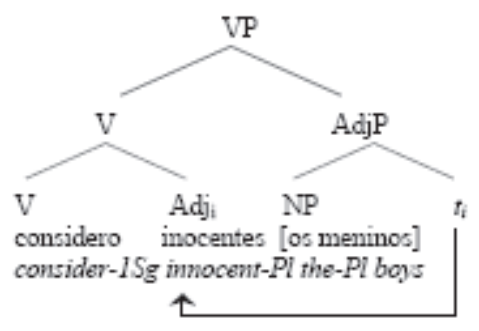

For Baker (1988) incorporation is a process that involves $\mathrm{X}^{\circ}$ movement and not XP-movement. If what is incorporated is just the head, we would expect, then, that adjectives, but not adjectival phrases could be moved. However, Brazilian Portuguese does not ban examples such as (15):

(15) Acho fácil de conseguir esses discos find-1Sg easy of get-Inf these records 'I find these records easy to get'

Likewise, we would expect nouns, but not noun phrases to be incorporated, but the expectation is not met:

(16) Acho um grande artista esse teu filho find $-1 S g$ a-Sg great $-S g$ artist-Sg this your $-S g$ son- $S g$ 'I find this son of yours to be a great artist'

Inversion is always possible in free small clauses with a more complex NP, but not natural with complex adjectives:

(17) Um grande artista esse seu filho!

$$
\text { a great artist this your son }
$$


(18) a. ?* Fácil de conseguir esses discos! easy of get-Inf these records

b. ?* Digno de piedade esses meninos! Worthy-Sg of pity these boys

Empirically, a counter-argument for the incorporation or restructuring hypothesis is the existence of the independent small clauses. If they are not complements of a matrix verb, how can their predicate be incorporated?

Moreover, even assuming that examples such as (15) are not incorporation cases, the concept of head would have to be relaxed for (19) to allow pre-head elements like intensifiers and articles to be invisible in incorporation:

(19) a. Maria acha um grande gênio o João

Maria finds a-Sg great-Sg genius-Sg the-Sg Joño

'Maria finds João to be a great genius'

b. Acho muito competente o seu secretário find-1Sg very competent $-S g$ the-Sg your-Sg secretary $-S g$ 'I find your secretary to be competent'

\subsection{The V-to-COMP Hypothesis}

As the landing site of $\mathrm{V}$ in V-to-Comp is COMP, we would have to assume that small clauses have COMP, an assumption contrary to what is currently believed. When compared to infinitival clauses, it will be evident that in the latter this node is well-motivated by wh-movement structures while with small clauses there is not such empirical motivation. Compare the two types of structure:

(20) [Você julgou [por quem $\mathrm{i}_{\mathrm{i}}$ estar [o Pedro apaixonado $t_{\mathrm{i}}$ ] ] $]$ you belived-3Sg with whom be-Inf the-Sg Pedro in.love

'With whom did you believe Pedro to be in love?'

(21) a. *[você julgou [por quem ${ }_{\mathrm{i}}$ [o Pedro apaixonado $t_{\mathrm{i}}$ ] $]$ ] you believed-3Sg with whom the-Sg Pedro in.love

b. *[você julgou por quem apaixonado $_{j}\left[0 \quad\right.$ Pedro $t_{j} t_{\mathrm{i}}$ ] ] you believed-3Sg with whom in-love the-Sg Pedro

c. [por quem [você julgou [o Pedro apaixonado]]] with whom you believed-3Sg the-Sg Pedro in.love 'With whom did you believe Peter in love?' 
The logical explanation for the fact that a wh-word in small clauses in $\mathrm{BP}$ only lands at the beginning of the root sentence is that they lack COMP, and consequently its specifier position.

However, V-to-COMP has been described as a main clause phenomenon and we have seen that small clauses must have inversion when they are independent forms, while they can have it when they are subordinated complement clauses. Let us suppose that small clauses may have a CP when they are free, that is when they are root phenomena.

Suppose that inversion in free small clauses is of the same nature as that of exclamative degree wh-sentences, like (22), in which the [wh+adjective] is unequivocally moved to Spec of CP, a plausible hypothesis considering the translation given for English.

(22) Quão inteligentes os meninos são! bow intelligent- $P l$ the- $P l$ boys are

'How intelligent these boys are!'

AGRP would not be a barrier for the [wh + adj] phrase movement, as the latter would be selected by the $[+$ wh $]$ feature of COMP.

However, we would be faced with three problems in this hypothesis. The first has to do with a cross linguistic difference. If English has wh-movement of [wh+adj], why is it that it does not have inversion in small clauses? The second has to do with the type of adjectives that can appear in $[w h+a d j]$ sentences and those that can appear in free small clauses. In the wh-adjective exclamations we can have both individual and stage-level adjectives:

(23) Quão inteligentes/problemáticos os meninos são! bow intelligent-Pl/problematic-Pl the-Pl boys are

'How intelligent/problematic the boys are!'

(24) Quão contentes/bêbados os homens estão!

how happy-Pl/drunk-Pl the men are

'How content/drunk the men are!'

The third argument to reject this solution is the obligatory SV order. VS order makes the sentence interrogative. Witness the contrast below: 
(25) a. Quão inteligente os meninos são!

how intelligent-Sg the-Pl boys are

'How intelligent the boys are!'

b. *Quão inteligente são os meninos!

how intelligent $-S g$ are the-pl boys

c. Quão inteligente são os meninos?

bow intelligent are the-Pl boys

'How intelligent are the boys?

In free small clauses we can have only adjectives selected by consider-type verbs, namely individual predicates:

(26) a. Inteligentes/problemáticos os meninos!

intelligent-Pl/problematic-Pl the-Pl boys

'How intelligent/problematic the boys are!'

b. *Contentes/bêbados os homens!

happy-Plldrunk-Pl the-Pl men

[Wh+adj] sentences, on the other hand, are selected by psych verbs and not consider-type verbs:

(27) I was surprised at how intelligent Bill is

As the lexical and syntactic differences between consider-type verbs and surprise-type predicates is the c-selection of $\mathrm{CP}$ versus some $\mathrm{XP}$ distinct from $\mathrm{CP}$, we will have to find a solution for the latter which is independent of movement.

\subsection{The romance inversion hypothesis}

It is a well-known fact that the so-called pro-drop languages exhibit the property of free subject predicate inversion, as was pointed out by Jaeggli (1981), Rizzi (1982), Torrego (1984), Barbosa (1995), and many others.

The property of subject-verb inversion that can be seen in the sentences below has been attributed to the pro-drop parameter, understood as a set of properties shared by many Romance languages. It has also been 
called 'free inversion' and has been exemplified with sentences like the following:

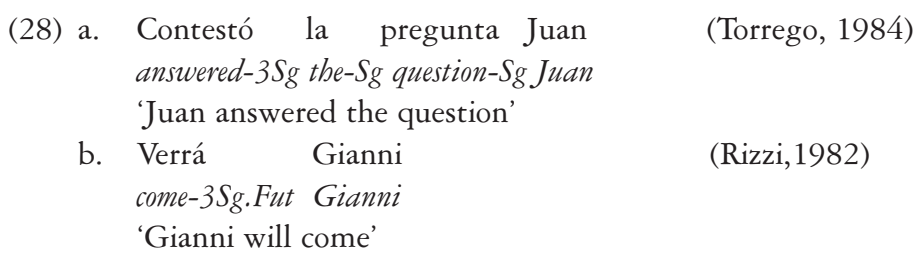

For Rizzi (1982) the postposed NP appears in adjunction to VP and is thus governed by INFL and assigned nominative case.

BP has been shown, however, to have inversion restricted to one argument verbs. This single-argument constraint (cf. Kato and Tarallo, 1988, 2003) is also operative in small clause constructions. Compare the restriction found in inflected clauses and small clauses:

(29) a. ??Comprou muita roupa, o João bought-3Sg many cloth the Joa a

b. *Guardou o carro na garagem, o Pedro put-3Sg the-Sg car-Sg in.the garage the-Sg Pedro

(30) a. ??Considero digno de Maria, o Pedro consider-1Sg worthy-Sg of Maria the-Sg Pedro

b. *Eu ví comprando roupa, o João I saw-1Sg buying cloth the-SgJoão

c. ?? Eu como assadas com carne, as cenouras I eat-1Sg baked-Pl with meat the-Pl carrots

d. *Eu descobri escondido no armário o dinheiro $I$ discovered-1Sg bidden-Sg in.the closet the-Sg money-Sg

Small clauses present, therefore, the same constraints of finite clauses, which makes us assume that the same licensing principles are operating in the small clause subject predicate inversion. However, Rizzi's proposal (or its variants) cannot be invoked for small clauses as, by definition, NPs and AdjPs lack tense inflection, which excludes assignment of nominative case by INFL within the small clause.

But the perfect parallelism between the constructions above and the forms below should be pointed out: 
(31) *São gênios em física esses meninos are genius-Pl in physics these boys

(32) ?? É digno de pena o João is worth-Sg of pity-Sg the-SgJoão

(33) *Estão cruas por fora as cenouras are raw-Pl on outside the-Pl carrots

(34) ?? Foi escondido no armário o dinheiro was-3Sg hidden-Sg in.the closet the-Sg money-Sg

Though VS structure is generalizable when the inflected verb or the copula is present, the same is not true when the non-verbal predication lacks the copula. In other words, stage-level predicates require the presence of estar, while individual level predicates can dispense with the copula ser.

Kato and Tarallo $(1988,2003)$ have proposed a different analysis for subject postposition in Brazilian Portuguese when the postposed subject has to be definite. They assume that the (NP, IP) position is filled by a referential pro and this empty category is, in its turn, co-referent to an NP in a right-dislocated position. They also claim that Brazilian Portuguese is losing its pro-drop properties and show that pro is in variation with a lexical resumptive pronoun in this context, the former being preferred when the verb is mono-argumental and the latter when it has more than one argument:

(35) a. Ele $e_{i}$ respondeu a pergunta, o João be answered-3Sg the question the- $\mathrm{Sg}$ Joa a

'João answered the question'

b. ??pro ${ }_{\mathrm{i}}$ respondeu a pergunta, o João ${ }_{\mathrm{i}}$ answered-3Sg the-Sg question-Sg the-SgJoão

(36) a. Ele telefonou o João

be telephoned-3Sg the-Sg João

'João called'

b. $p r_{\mathrm{i}}$ telefonou o João ${ }_{\mathrm{i}}$

telephoned $-3 S g$ the-Sg Joa o

'João called'

Strict pro-drop languages like Italian and Spanish are assumed to have an expletive pro instead of a referential pro in the subject position and the 
postposed noun would be less external than the antitopic position in Brazilian Portuguese. Lexical pronouns, which seem to be always referential in these languages, can only alternate with referential pro and not with expletive pro.

(37) a. pro/*el telefonó um homem

he telephoned-3Sg a man

'A man called'

b. pro/*el telefonó, Juan

he telephoned-3Sg Juan

'Juan called'

(38) a. pro/*el contestó la pregunta un joven

he answered-3Sg the-Sg question- $S g$ a-Sg youngster-Sg

'A youngster answered the question'

b. pro/*él contestó la pregunta, Juan

be answered-3Sg the-Sg question-Sg, Juan

'Juan answered the question'

The change from a pro-drop to a non-pro-drop language seems to be a function of the re-analysis of the pro from a non-referential to a referential interpretation in these contexts. ${ }^{4}$

We could argue then that in Brazilian Portuguese the same sort of right-dislocation structure is involved in (31)-(34) above.

(39) a. Eles sâo inteligentes, esses meninos

they are intelligent- $P$ l these boys

'These boys are intelligent'

b. Ele é um gênio, o João

he is a-Sg genius $-\mathrm{Sg}$ the-Sg João

'João is a genius'

c. Elas sairam as visitas

they left-Pl the-Pl guests

'The guests left'

d. Elas estão cruas, as cenouras

they are raw-Pl the-Pl carrots

'The carrots are raw'

e. Ele foi escondido, o dinheiro

he was-3Sg hidden-Sg the money-Sg

'The money was hidden'

4 This does not mean that non-referential pro in impersonal or expletive constructions is also reanalyzed. 
Though both a pronoun and a pro are licensed in these sentences - by INFL in finite sentences and by the external verb in complement sentences -, the question is how pro in free small clauses would be licensed. Besides, pro in small clauses would never alternate with a lexical pronoun which is always referential - in such constructions, which seems to indicate that that position is not assigned case:

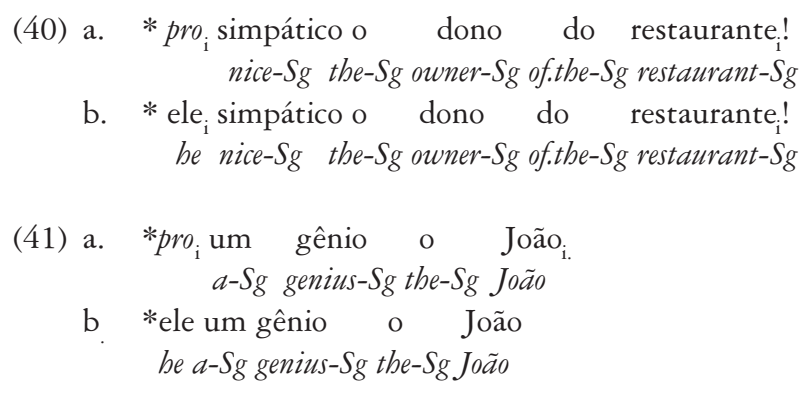

As we cannot have a referential pro let us assume that in small clauses, BP is like Spanish and Italian having expletive pro instead of referential pro. We might claim that here case is not required for the subject as no theta-role would be assigned in this position. However, as the postposed NP cannot get case either, there being no INFL to assign it, and no case-marked expletive from which it can inherit its case, and the clause would violate the visibility condition.

We are claiming therefore that at least for free small clauses inversion cannot be explained in terms of Romance inversion, at least in its referential pro version, which is the case of $\mathrm{BP}$.

\subsection{The ergative / unaccusative hypothesis}

Kato and Tarallo $(1988,2003)$ have shown that, though Brazilian Portuguese has lost Romance inversion, ergative and unaccusative constructions are still quite productive and, while referential subjects tend to be filled by lexical pronouns, the expletive pronoun is still categorically null.

The consideration of adjectives as ergative predicates was defended by Cinque (1988) in his analysis of a certain class of adjectives in Italian. Among his empirical arguments are: 
Ne-cliticization from inverted subjects is only possible with ergative predicates ${ }^{5}$

(42) a. $\mathrm{Ne}_{\mathrm{i}}$ ha affondate $\left[\right.$ due $\left._{\mathrm{i}}\right]$

(Ergative Verb)

of.them has- $3 S g$ sank

two

'Two of them sank'

b. $\mathrm{Ne}$ sono $_{\mathrm{i}}$ note $\left[\right.$ le tendenze $\left.t_{\mathrm{i}}\right]$

(Ergative adjective)

of.them are known the tendencies

'Their tendencies are known'

c $\quad * \mathrm{Ne}_{\mathrm{i}}$ sono buone [le intenzioni $t_{\mathrm{i}}$ ] (Non-ergative adjective) of.them are good the intentions

'Their intentions are good'

\section{Wh-extraction from the inverted sentential subject ${ }^{6}$}

(43) a. A Mario, di cui é nota/iminente una presa di posizione sul tema to Mario, of whom is known/evident a position about issue 'Mario, of whom it is known a position taken about the issue'

b. * A Mario, di cui é periculosa/ingiustificata una presa di posizione sul tema Mario of whom is dangerous /unjustified a position subject about issue

\section{Short distance binding within the subject ${ }^{7}$}

(44) a. Il proprio $_{i}$ destino non era noto a nessuno bis own destiny non was known to anybody

'His own destiny was not known to anybody'

b. *Il proprio figli sono fideli a tutti ${ }_{i}$ bis own children are faithful to everybody

5 This property is not relevant for $\mathrm{BP}$ as it has no ne-cliticization.

6 This is parallel to what happens with regard to the ergative adjectives, and the unergative injustificada 'unjustified', but not with perigosa 'danger':

(i) a. O Mario, de quem é bem conhecida a afirmação sobre o assunto... the-Sg Mario, of whom is well known the $-S g$ assertion- $-S g$ about the $-S g$ subject $-S g$

'Mario, of whom it is known the assertion about the issue...'

b. O Mario, de quem é injustificada/*perigosa a afirmação de que ... the-Sg Mario, of whom is unjustified/danger-Sg the-Sg assertion-Sg of that...

'Mario, of whom it is unjustified/dangerous the assertion that (...)'

7 This property does not hold for BP. Both (a) and (b) are bad in BP. 
Long distance binding 8

(45) a. Gianni ì è [riconoscente a chiunque aiuti i propri ${ }_{\mathrm{i}}$ amici]

Gianni is grateful to whoever helps the own friends

'Gianni is greatful to whoever helps his friends'

b. *[Un discorso del genere $]_{\mathrm{i}}$ è chiaro solo a chi conosce la propria ${ }_{\mathrm{i}}$ logica $]$ a speech of the type is clear only to who know-3Sg the own logic

'Such speech is clear only to those who know its own logic' (with propria referring to un discorso del genere)

Though Cinque's properties do not distinguish different types of adjectives in BP, except for the second one, assuming that BP also splits the class of adjectives into intransitives and ergatives, we may try to find the properties that distinguish the two classes in this language. It seems that in Brazilian Portuguese it would be fairly correct to assume that adjectives that can occur both with the copula ser and estar are the ergative ones as they correlate with the possibility/impossibility of appearing with postposed subjects:

(46) a. Esta menina é linda

this girl-Sg is beautiful-Sg

'This girl is beautiful'

b. Esta menina está linda this girl-Sg is beautiful-Sg

'This girl looks beautiful'

c. Linda esta menina!

beautiful-Sg this girl-Sg

'This girl is beautiful!'

(47) a. João está bêbado

João is drunk-Sg

'João is drunk'

b. *João é bêbado

João is drunk-Sg

c. *Muito bêbado esse amigo seu

very drunk-Sg this friend-Sg your

However, there is a class of ergative adjectives which take propositions and not entities as arguments (event adjectives in Cinque's sense), and in this case the copula is always ser: 
(48) É curioso que João venha is curious that João come-3Sg-Sbjnctv

'It is curious that João come'

(49) É impressionante que João tenha sido condenado is impressive that João have-3Sg-Sbjnctv been condemned-Sg 'It is unbelievable that João was condemned'

These propositional adjectives can also appear in free small clauses, though they prefer infinitival or deverbal complements rather than full finite clauses:

(50) Curioso o João não ter vindo! curious the-SgJoão not have-Inf come 'João not coming was curious!'

(51) Impressionante a condenação do João! impressive the-Sg condemnation-Sg of.the-SgJohn 'João's condemnation was unbelievable!'

Verbs of judgement like considerar 'consider' and achar 'find' select ergative adjective small clauses:

(52) a. Eu acho linda/inteligente esta menina

I find-1Sg beautiful-Sg/intelligent-Sg this girl-Sg

'I find this girl beautiful/intelligent'

b * Eu considero bêbado/contente este homem

I consider-1Sg drunk/content-Sg this man

(53) Eu considero impressionante a condenacão do João $I$ consider-1Sg impressive- $S g$ the-Sg condemnation- $S g$ of.the- $S g$ Joa o 'I consider João's condemnation unbelievable'

When the complement of the verb is a finite clause, the non-ergative adjective can occur:

(54) Eu acho que este homem está bêbado

I guess-1Sg that this man is drunk-Sg

'I guess that this man is drunk' 
Another context, which distinguishes ergatives from unergatives, is the position of subject complements as noted by Raposo and Uriagereka (1995), who only use the individual-stage level distinction, and not the ergative-non-ergative one:

(55) a. Luiz saiu da festa bêbado/cansado Luiz left-3Sg of.the-Sg party-Sg drunk-Sg/tired-Sg

'Luiz left the party drunk/tired'

b. *Luiz saiu da festa inteligente/simpático Luiz left-3Sg of.the-Sg party-Sg intelligent/charming-Sg

Cinque observes that in small clause complements in Italian the behavior of ergative and unergative adjectives is the same, both allowing inverted subjects, which makes him adopt the restructuring hypothesis:

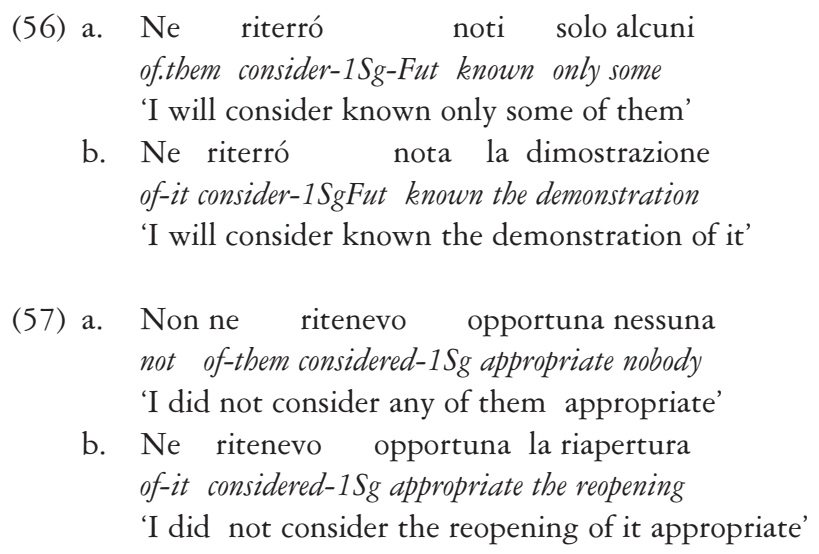

The adjective opportuna, considered by Cinque to be unergative in Italian, has an identical lexical item in Portuguese, which behaves like the ergative ones, appearing in free small clause and prenominal position:

(58) Muito oportuna a reabertura!

very appropriate- $S g$ the- $S g$ reopening- $S g$

'How appropriate the reopening!'

As oportuna requires a complement with a propositional nature, it is restricted to co-occur with ser. 
(59) a. A reabertura é oportuna the- $S g$ reopening- $S g$ is appropriate- $S g$

'The reopening is appropriate'

b. *A reabertura está oportuna

the-Sg reopenning-Sg is appropriate- $S g$

c. É oportuno que haja reabertura is appropriate that have-3Sg-Sbjnctv reopening 'It is appropriate that there be reopening'

I will assume, therefore, that oportuno is a propositional ergative adjective in BP.

It should be pointed out, however, that cases of "inversion" with ergative adjectives can have two different S-structure representations. One is the pure ergative construction and the other is right dislocation structure with an empty resumptive pronoun (as discussed in section 3):

(60) a. [pró é [oportuna a reabertura]

is appropriate the-Sg reopening-Sg

b. $\quad\left[p r o_{\mathrm{i}}\right.$ é [oportuna $\left.\left.t_{i}\right]\right\}[\mathrm{a} \text { reabertura }]_{\mathrm{i}}$ is appropriate the-Sg reopening- $S g$

In (60b) the NP a abertura would be in an $\mathrm{A}^{\prime}$ position co-indexed to pro, which is, thus, referential, differing from the expletive pro in (60a). Unergative adjectives can have 'inverted' structures represented in (60b) but not in (60a). The possibility of null subject languages to have a pro in subject position obscures the difference between an ergative construction with an expletive subject and a construction with an ergative/unergative verb with a pro subject coindexed with a NP in an $\mathrm{A}^{\prime}$ position.

(61) a. *[pro está [contente a menina]

$$
\text { is happy-Sg the-Sg girl-Sg }
$$

b. $\quad\left[\right.$ pro $_{\mathrm{i}}$ está [contente $]$ [a menina $]_{\mathrm{i}}$

is happy-Sg the-Sg girl-Sg

A fourth characteristic of ergative adjectives (the first being their appearance in free small clauses, the second their occurrence with both ser and estar and the third, their inability to appear as subject complements, as seen in Raposo and Uriagereka, 1995) is their position regarding nouns in a noun phrase. In Brazilian Portuguese the adjective can be either preno- 
minal or postnominal, the former position being more restricted. All ergative adjectives can appear both in pre-nominal and postnominal positions. Unergatives, which co-occur only with estar, appear only in post-nominal position.

'Ser' and 'estar' adjectives (ergatives)

(62) a. A linda menina

the-Sg beautiful-Sg girl-Sg

'The beautiful girl'

b. A inteligente solução

the- $\mathrm{Sg}$ intelligent- $\mathrm{Sg}$ solution- $\mathrm{Sg}$

'The intelligent solution'

c. A menina linda

the-Sg girl-Sg beautiful-Sg

'The beautiful girl'

d. A solução inteligente

the- $\mathrm{Sg}$ solution- $\mathrm{Sg}$ intelligent $-\mathrm{Sg}$

'The intelligent solution'

Only 'ser' adjectives (propositional ergatives):
(63) a. Uma curiosa reação
a- $S g$ curious $-S g$ reaction $-S g$
'A curious reaction'
b. A oportuna solução
the-Sg providential-Sg solution- $S g$
'The providential solution'
c. Uma reação curiosa
a- $S g$ reaction $-S g$ curious $-S g$
d. A solução oportuna
the $-\mathrm{Sg}$ solution $-\mathrm{Sg}$ providential-Sg
'The providential solution'

Only 'estar' adjectives (unergatives)

(64) a. *A grávida mulher

the-Sg pregnant-Sg woman

b. *O bêbado homem

the-Sg drunk-Sg man

c. A mulher grávida

the-Sg woman pregnant-Sg

'The pregnant woman' 
d. o homem bêbado

the-Sg man drunk-Sg

'The drunk man'

We have so far established two types of adjectives in BP, the ones we will be calling ergatives, and the non-ergative ones, the latter not licensed in free small clauses. The claim that we would like to make here is that the order predicate-subject in small clauses is a base order with the selected NP generated as an internal argument of the ergative adjective or noun, exactly like in unaccusative constructions. The internal NP would optionally raise to the empty subject position.

The derivation of ordinary finite sentences with ser and estar are assumed to be as follows:

(65) Estas meninas são inteligentes

these girl-Pl are intelligent- $P l$

'The girls are intelligent'

(66) a. $\mathrm{L}_{\mathrm{AP}}$ inteligentes [estas meninas]]

b. $\operatorname{ser}\left[_{A P}\right.$ inteligentes [estas meninas]]

c. INFL $+\operatorname{ser}\left[_{\mathrm{AP}}\right.$ inteligentes [estas meninas]]

d. são [inteligentes estas meninas]

or

d'. [Estas meninas $]_{\mathrm{i}}$ são [inteligentes[ $\left[t_{i}\right]$ ]

(67) A moça está grávida

the-Sg girl-Sg is pregnant $-\mathrm{Sg}$

'The girl is pregnant'

(68) a. $\complement_{A P}$ a moça [grávida]]

b. INFL + estar [a moça [grávida]]

c. [a moça $]_{\mathrm{i}}$ está $\left[t_{\mathrm{i}}\right.$ [grávida $\left.]\right\}$

In (66d) nominative case assignment to estas meninas is obtained through Agree, with [INFL+ser $]$ acting as probe (cf. Chomsky 1998). In (66d'), estas meninas raises to [Spec,INFL], where it checks case and EPP. With non-ergative adjectives, only raising is possible.

The same contrast is observed between unaccusative verbs and unergative verbs. With the latter, only raising is possible. 
(69) a. Chegaram os ovos 9

arrived-3Pl the-Pl eggs

'The eggs arrived'

b. Os ovos chegaram

the-Pl eggs arrived-Pl

'The eggs arrived'

(70) a. *Tossiu o menino

coughed-3Sg the-Sg boys

'The boy coughed'

b. O menino tossiu

the-Sg boy-Sg coughed-3Sg

'The boy coughed'

Summing up, the difference between ser and estar, seems to be in the fact that ser is an optional raising verb, while estar is a strict raising verb. But this is not enough to account for free small clauses, in which there seems to be no case-licenser for the postposed DP. ${ }^{10}$

\section{Our analysis: the third copula}

Before we give a final solution to free small clauses, we will first examine the semantic interpretation of its predicate. Thus, observe the following pair of sentences:

(70) a. É INTELIGENTE que o menino é is intelligent that the-Sg boy-Sg is

'It is intelligent that the boy is'

b. É BÊBADO que o homem está

is drunk-Sg that the-Sg man is

'It is drunk that the man is'

Both the individual level and the stage level adjectives have a 'focus' or 'emphasis' reading (represented in block letters), and the main clause

9 In the vernacular, agreement is lost, as shown in (i).

(i) Chegou os ovos

arrived- $3 \mathrm{Sg}$ the- $\mathrm{Pl}$ eggs

'The eggs arrived'

10 We could consider the partitive case proposed by Belletti (1988) for unaccusative arguments, but the semantic import of this case is that it is always indefinite, while in free small clauses, the postposed subject is always definite. 
copula is not constrained by the copulas - ser or estar - that appear in the finite embedded clause.

(71) a. É E $\mathrm{L}_{\mathrm{FP}}\left[\mathrm{IINTELIGENTE}_{+\mathrm{F}}\right]_{\mathrm{i}} \mathrm{que}_{+\mathrm{F}} \mathrm{L}_{\mathrm{IP}} \mathrm{O}$ menino é $\left.\left.\left.t_{\mathrm{i}}\right]\right]\right]$

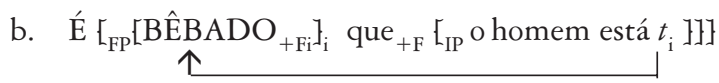

The cleft sentence is analyzed as resulting from the movement of the predicate with $+\mathrm{F}$ features to the lower sentence FP position, right adjacent to the finite verb, a position licensed for non-V2 languages (Kato and Ribeiro, 2006). We may now consider that instead of a finite sentence with the complementizer que 'that', we can have a small clause, which is also assumed to license an FP position, in the sense of Belletti's (2004, 2005) proposal:

(72) a. $\left[_{\mathrm{AP}}\right.$ inteligente $_{+\mathrm{F}}$ [este menino $\left.]\right]$

b. $\quad \mathrm{E}_{\mathrm{AP}}\left[\text { INTELIGENTE }_{+\mathrm{F}}\right]_{\mathrm{i}} \mathrm{L}_{\mathrm{AP}} t_{\mathrm{i}}$ [ [este menino $\left.\left.]\right\}\right]$

c. É $\left[_{\mathrm{FP}}\left[\text { INTELIGENTE }_{+\mathrm{F}}\right]_{\mathrm{i}} \mathrm{F}_{\mathrm{AP}_{\mathrm{AP}}} t_{\mathrm{i}}\right.$ [este menino $\left.\left.]\right\}\right]$

We claim, moreover, that the third copula is not a raising verb like the attributive copula we saw above, but a small $v$, with less substantive content than a full V. ${ }^{11}$ If the AP has no FP extension, the predicate can undergo movement to $\mathrm{CP} / \mathrm{FP}$, where it can also have the $+\mathrm{F}$ feature checked:

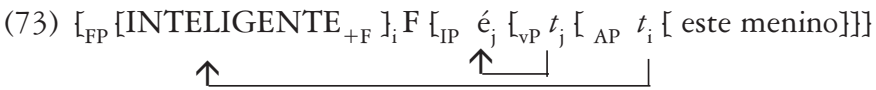

The copula + INFL is also a probe for case and $j$-feature checking:

(74) São INTELIGENTES estes meninos

Our last claim is that the third copula can be erased at PF, when in sentence initial position, yielding the free small clauses we have been trying to analyze.

(75) [são-INTELIGENTES estes meninos]

\footnotetext{
11 I am assuming that being a $v$, and not a full $\mathrm{V}$, the third copula cannot have predicates incorporated into it.
} 
Now, recall that stage-level predicates have obligatory raising, and, therefore, a small clause containing them is incompatible with the third copula, which either selects a $\mathrm{CP}$ or a small clause containing an ergative predicate. However, recall that this restriction does not hold if estar appears inside $\mathrm{CP}$.

\section{Small children's free small clauses}

Since Brown's (1973) seminal work, child language has been shown to contain copula-drop, both as the main verb and the auxiliary:

(76) a. you lazy

b. I putting supper on the table

Radford (1990) builds a theory in which this is because small children speak small clauses, and these include predication without the copula. For Radford, the subject in children's small clauses are licensed through a 'default' accusative case (me tired).

Schütze (ms.) assigns V-status to the copula and relates copula-drop to the Optional Infinitive phenomenon, namely to underspecification of Tense.

We might wonder whether free small clauses in BP share any property with children's small clauses. The following facts lead us to claim that we have distinct phenomena, for the following reasons: First, children's free small clauses are not restricted to individual level predicates. In fact, the auxiliary be is stage level. Second, semantically, the predicate in children's small clauses is the informational focus while in BP free small clauses, the predicate is the narrow focus and the subject a presupposed element in the context. Third, considering that in null subject languages the default case is nominative, the subject in BP should be nominative by 'default'. But the loss of clitics in BP does not allow full testing of the subject pronominal form, except for the first person, which still has an asymmetry between nominative and accusative. However, BP free small clauses refer mostly to the addressee or a third party, and not to the first person. 
(77) a. Interesseiro você/ele

gold-digging you/he

'What a gold-digging person you are/he is!'

b. Um burro eu

a donkey I

'How stupid of me'

Notice that a common property is the copula-drop. However, we saw in our analysis that it is not any copula that can be erased in adult free small clauses in BP, but only the third. Despite this erasure property, we support Schütze's claim that be is a $\mathrm{V}$ and not an INFL. The case of the postposed DP is valued as nominative by Agree, by the main clause INFL, and not a 'default' nominative.

\section{Concluding remarks}

$\mathrm{BP}$ was shown to have three kinds of adjectives, the ones that can occur with the copulas ser and estar, or the individual predicates, the ones that can occur only with the second type of copula (estar), or stage level predicates, and the ones that occur only with the first copula, namely the event type of adjective in Cinque's sense. We considered the individual and event types as ergative adjectives, and the stage level ones as nonergatives. The ergative ones were claimed to have an internal argument, and the non-ergative ones, an external argument.

We also considered three kinds of copula: the attributive copula ser (the first), the stage level copula estar (the second), and a third copula, a V, homophonous with the first, with the following properties:

Syntactically

(i) It selects a clausal complement, whether a $\mathrm{CP}$ or a small clause;

(ii) In the latter case it precludes raising.

\section{Semantically}

(iii) Its predicate is assigned a Focus reading;

\section{Phonologically}

(iv) Phonologically it can be erased when it is in sentence initial position. 
The third property is what distinguishes a normal, non-finite cleft type of construction from free small clauses.

In short, adult small clauses in BP are ordinary finite cleft sentences.

E-mail:ma.kato@uol.com.br

\section{REFERENCES}

BAKER, M. 1988. Incorporation; A theory of grammatical-function changing. Chicago: Chicago University Press.

Barbosa, P. 1995. Null subjects. PhD dissertation, MIT.

Belletti, A. 1888. The case of unaccusatives. Linguistic Inquiry 19: 1-34. . 2004. Aspects of the low IP area. In: L. Rizzi (ed.) The structure of CP and IP. The cartography of syntactic structures. Vol. 2. New York: Oxford University Press. 16-51. . 2005. Answering with a "cleft": the role of the null subject parameter and the VP periphery. In: L. BRUYE et alii. (eds.) Proceedings of the $13^{\text {th }}$ Incontro de Grammatica Generativa. Venice: Cafoscarina. 6382.

BRown, R. 1973. A first language: the early stages. Cambridge, Massachusetts: Harvard University Press.

Chomsky, N. 1981. Lectures on government and binding. Dordrecht:Foris. . 1998. Minimalist inquiries: the framework. MIT Occasional Papers in Linguistics 15.

Chung, S. \& J. McCloskey. 1987. Government, barriers, and small clauses in Modern Irish. Linguistic Inquiry 18.2:173-237.

CinQue, G. 1990. Ergative adjectives and the lexicalist hypothesis. Natural Language E Linguistic Theory 8.1: 1-39.

Do Nascimento, M. 1984. Sur la postposition du sujet dans le Portugais du Brésil. Doctoral thesis, Université de Paris VIII.

Emonds, J.E. 1985. A unified theory of syntactic categories. Dordrecht: Foris. JAEGGLI, O. 1984. Subject extraction and the null subject parameter. Proceedings of NELS 14: 132-153.

Kitagawa, Y. 1985. Small but clausal. Proceedings of CLS 21: 210-220.

KURODA, Y. 1986. Whether we agree or not: a comparative syntax of English and Japanese. Linguisticae Investigationes 12.1: 1-47. 
Kato, M. A. and I. Ribeiro. 2007. A evolução das estruturas clivadas no português. In: T. Lobo, I. Ribeiro, Z. Carneiro \& N. Almeida (eds.) Para a bistória do português brasileiro. Vol 6: A experiência dos grupos de estudo. Tomo I. Salvador: EDUFBA. 165-182.

\& F. Tarallo. 1988. Restrictive VS syntax in Brazilian Portuguese and its relation to visible subjects and invisible clitics. Paper presented at The 1988 Georgetown Roundtable in Languages and Linguistics.

. 2003. The loss of VS syntax in Brazilian Portuguese. In: S. LANGE, I. KOCH \& K.

JungBLuTH (eds.) Dialogue between schools: sociolinguistics, conversational analysis and generative theory in Brazil. Münster: Nodus Publicationen, Klaus D. Ditz. 101-129.

McCloskey 1986. Government, barriers and small clauses in Modern Irish. Linguistic Inquiry 18:173-237.

RADFORD, A. 1990. Syntactic theory and the acquisition of English syntax. Oxford: Blackwell.

Raposo, E. and J. Uriagereka (1995). Two types of small clauses. In: A. Cardinaletti \& M.T. Guasti (eds.) Small clauses. New York: Academic Press. 179-206.

Rizzi, L. 1982. Issues in Italian syntax. Dordrecht: Foris.

Rothstein, S. 1983. The syntactic forms of predication. PhD dissertation, MIT. SAFIR, K. 1984. On small clauses as constituents. Linguistic Inquiry 14.4:730-735.

SCHÜTZE, C.T. Why nonfinite be is not omitted while finite be is. Ms, UCLA.

STOWELL, T. 1981. Origins of phrase structure $\mathrm{PhD}$ dissertation, MIT

Stowell, T.1991. Small clause restructuring. In: R. Freidin (ed.) Principles and parameters in comparative grammar. Cambridge: MIT Press. 182218.

Torrego, E. 1984. On inversion in Spanish and some of its effects. Linguistic Inquiry 15: 103-129.

WilLIAMs, E. 1983. Against small clauses. Linguistic Inquiry. 14.2: 287-308. 